
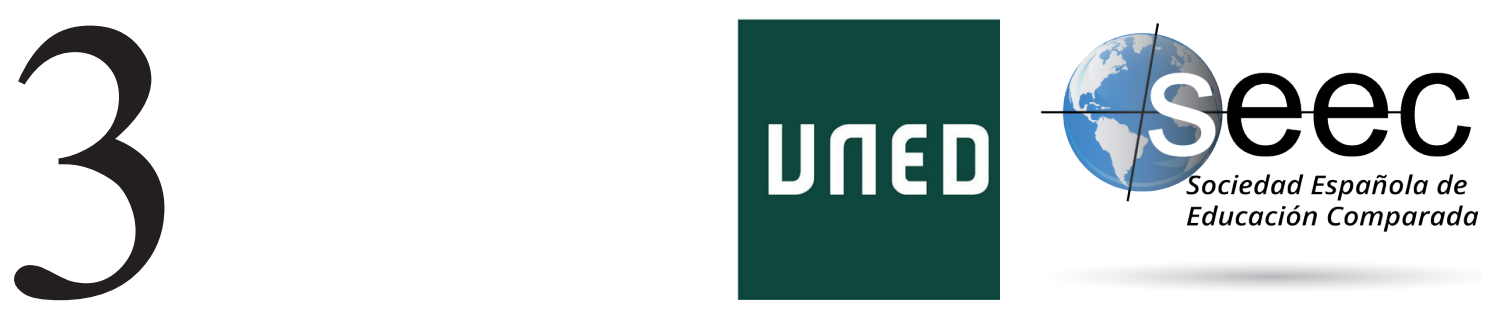

\title{
European cooperation in vocational education and training: towards a common ambition
}

Cooperación europea en la formación profesional: hacia una meta común

\section{Irene Psifidou*; Antonio Ranieri **}

DOI: 10.5944/reec.36.2020.26879

\author{
Recibido: 23 de febrero de 2020 \\ Aceptado: 8 de junio de 2020
}

\footnotetext{
*Irene Psifidou: is an expert on European education and training policies at the European Center for the Development of Vocational Training (Cedefop). Datos de contacto: E-mail: rena.psifidou@cedefop.europa.eu *ANTonio Ranieri: Head of Department for Learning and Employability at the European Center for the Development of Vocational Training (Cedefop). Datos de contacto: E-mail: antonio.ranieri@cedefop.europa.eu
} 


\begin{abstract}
As the policy cycle for European cooperation in vocational education and training (VET) is coming to an end in 2020, the need for high-skilled labour is increasingly seen as paramount to ensure future sustainable and inclusive development in Europe. Drawing on Cedefop review and analysis of VET policies and their implementation, this article provides a brief overview of the progress made so far, areas of weakness, and persistent and new challenges ahead. Analysis confirms the gradual but continuous progress being made over the last decade despite the years spent in the long shadow of the financial crisis and the consequent economic and political uncertainty affecting many European countries. While participation to and, importantly, quality of VET varies across national systems, most Member States have progressed towards the achievements set in the Bruges Communique in 2010. This includes improved transparency, quality assurance and permeability of national qualification systems, as well as the enhanced responsiveness of VET provision to labour market needs through the wider recognition of the role of work-based learning and apprenticeship schemes. What is apparent today, more than ever before, is that the European institutional and policy framework represents a unique strength for Member States to focus on the big picture over the long term and make the most of the opportunities that an enhanced cooperation among national systems may offer to improve the overall performance, quality and attractiveness of VET in Europe.
\end{abstract}

Keywords: Vocational education and training; adult learning; European policy cooperation; education and training framework 2020; skills; labour market

\title{
Resumen
}

A medida que el ciclo para la cooperación europea en educación y formación profesional (FP) está llegando a su fin en 2020, la necesidad de mano de obra altamente calificada se considera cada vez más importante para garantizar un futuro desarrollo sostenible e inclusivo en Europa. Basándose en el examen y análisis de Cedefop de las políticas de FP y su implementación, este documento proporciona una breve descripción del progreso realizado hasta el momento, áreas de debilidad y desafíos persistentes y nuevos por delante. El análisis confirma el progreso gradual pero continuo realizado en la última década, a pesar de los años transcurridos a la larga sombra de la crisis financiera y la consiguiente incertidumbre económica y política que afecta a muchos países europeos. Si bien la participación en la FP y, lo que es más importante, su calidad, varían en los diferentes sistemas nacionales, la mayoría de los Estados Miembros han progresado hacia los logros establecidos en el Comunicado de Brujas en 2010. Esto incluye una mayor transparencia, garantía de calidad y permeabilidad de los sistemas nacionales de calificación, así como una mayor capacidad de respuesta de la provisión de FP a las necesidades del mercado laboral, a través de un reconocimiento más amplio del rol del aprendizaje basado en el trabajo y los esquemas de formación. Lo que es evidente hoy, más que nunca, es que el marco institucional y político europeo representa una fuerza única para que los Estados Miembros se centren en el panorama general a largo plazo y aprovechen al máximo las oportunidades que puede ofrecer una mayor cooperación entre los sistemas nacionales para mejorar el rendimiento general, calidad y atractivo de la FP en Europa.

Palabras clave: Formación profesional; aprendizaje de adultos; cooperación política europea; marco de educación y formación 2020; competencias; mercado laboral 


\section{Introduction}

2020 marks the conclusion of the vocational education and training (VET) European policy framework and its new post-2020 era. The 2010 s had begun with stagnant economy and shrinking employment opportunities that required immediate mitigating policy actions. The decade is ending with a greater focus on the long-term challenges facing Europe, including labour market developments due to demographic change, the greening of the economy, accelerating technological change and digitalisation of work.

In this perspective, new vision and policy framework are being developed under the guidance of the new European Commission that took office in 2019. This new strategic framework will build on the achievements in the past ten years in the overall Europe 2020 strategy and its targets, including the education and training framework (ET2020), the adult learning and skills agendas and the joint work on VET. At the same time, the new policy framework will inevitably have to address the multi-facetted challenges in an ever more rapidly evolving environment which makes investing in people and their knowledge, skills and competences throughout their lives paramount and difficult to achieve.

This is already reflected in the proposed financial framework for the EU in 2021-27. By creating synergies between several existing programmes ${ }^{1}$, the new ESF+ will provide comprehensive support to youth employment, up- and re-skilling of workers, social inclusion and poverty. All people, whether young or adults, employed or jobless and irrespective of their qualification levels need to have the opportunity to develop, update and upgrade their skills to keep up with rapidly changing work realities, succeed in their personal lives and contribute actively to a cohesive society based on European common values and tolerance.

This ambitious aim also requires quality jobs and making the best possible use of the skills people possess, as well as addressing skills gaps in support of Europe's long-term goals, including inclusive innovation for sustainable development. In this perspective, the challenge of all challenges will be to reconcile short-term and forward-looking policy approaches while simultaneously addressing multiple dynamic technological, economic, environmental, demographic and social challenges. Located at the intersection of education, economic, industrial, employment and social policy, VET and adult learning policies have the potential to play a pivotal role in this context.

A new strategy for the future development of VET needs to acknowledge achievements met and have a deep understanding of the challenges ahead. In 2002, the Member States of the European Union launched the Copenhagen process ${ }^{2}$, to strengthen and better coordinate their VET policies. This process has been developed through several Ministerial meetings and policy documents, in particular the Bruges Communiqué in 2010, and the Riga Conclusions in 2015, where the European Commission, EU Member States and social partners reaffirmed their commitment to inclusive and high quality VET. The Riga Conclusions widened the scope of European VET policies, while setting five specific medium-term priorities for the period 2015-2020 to make them 'more relevant to current and future labour markets'. For a decade now, Cedefop, the European Centre for the Development of Vocational education and training has been monitoring national policy developments towards the achievement of the Riga conclusions (see Box 1).

1 Namely, the European Social Fund, the Youth Employment Initiative, the Fund for European Aid to the Most Deprived, the Employment and Social Innovation programme and the Health programme.

2 https://www.cedefop.europa.eu/files/copenahagen_declaration_en.pdf 
Box 1.

Cedefop in brief

Cedefop is the European Union's reference centre for vocational education and training (VET). By working together with the Commission, the Member States and the social partners, Cedefop's objective is to support the promotion, development and implementation of Union policies in the field of vocational education and training as well as skills and qualifications policies. Since its foundation in 1975, Cedefop role has therefore evolved in line with the expanding role of vocational training policies such as those related to skills intelligence, the validation of learning and qualifications which go beyond the traditional boundaries of VET.

Source: on the basis of Cedefop Founding Regulation 2019

Drawing on Cedefop evidence and analysis of policy developments in VET and adult learning across the EU-28+ countries ${ }^{3}$, in chapter 2 this paper provides a brief overview of the European cooperation over the past decade towards a common ambition for modernizing VET in Europe Chapter 3 focuses on some trends and emerging challenges as suggested points of reflection for shaping future policy action. Finally, chapter 4 provides some concluding remarks in a forward-looking perspective.

\section{European cooperation in VET: from Copenhagen to Bruges and Riga}

Vocational education and training (VET) has been an important part of EU policy since the very establishment of the European Community. Since 2002, European cooperation on VET has been shaped under the Copenhagen process and taken forward through a series key policy documents, common objectives, and actions that represent today the policy framework under which EU Member States are developing their national VET systems. Despite many differences in the starting point, purpose, speed of change and progress made, evidence furnished by Cedefop reveals that VET systems in countries all around Europe have moved forward to establish VET as a credible first choice. A brief overview of these policy developments can be provided drawing on Cedefop's systematic monitoring ${ }^{4}$ of VET developments in EU $28+5$ as well as other comparative Cedefop comparative research work.

\subsection{Working on a common vision}

The grounds for European cooperation in VET had already implicitly been laid in the 1951 agreement establishing the European Coal and Steel Community ${ }^{6}$ and then in the

$3 \quad$ European Member States (EU28) plus Iceland and Norway. Cedefop's research and monitoring exercises contain UK data and analysis based on research conducted before the United Kingdom's exit from the European Union on 31 January 2020. Data coming from UK were collected, processed and published before its withdrawal from the EU.

4 Cedefop policy reporting findings are available here: https://www.cedefop.europa.eu/en/eventsand-projects/projects/reporting-european-training-policy

$5 \quad$ EU Member States before the UK's exit on 31/1/20 (see footnote 3), plus Norway and Iceland.

6 Measures taken within the European Coal and Steel Community already concerned issues that are topical today: anticipating and better matching skills supply and demand, removing mobility obstacles and 
Treaty of Rome (Articles 118 and 128), the latter defining the goal of developing a common policy on vocational education and training. VET was seen as a social policy lever, and the European Social Fund supported retraining of the unemployed. While the term 'vocational training' was not defined, it is commonly understood as comprising initial training, skills updating and retraining and therefore addressing both young people and adults (Cedefop, 2004).

Today, cooperation in this area is anchored in the Treaty of Lisbon which calls for the Union to implement "a vocational training policy" (Article 166 TFEU). Since 2002, this policy and European cooperation in VET have evolved under the framework of the Copenhagen process (The Copenhagen declaration, 2002) based on complex multilevel governance (see Box 2).

Box 2.

Governance of European Union cooperation in VET

The overall governance of European Union cooperation in VET is structured around the meetings of the Directors General for Vocational Education and Training (DGVT), giving the policy steer, and the formal Advisory Committee on Vocational Training (ACVT) whose role is to advise the Commission in implementing a Community vocational training policy. In addition, the European Centre for the Development of Vocational Training (Cedefop) supports development of European VET policies and contributes to their implementation under-pinned by its research, analyses and information on VET systems, policies and practice, skill needs and demands in the EU. The European Training Foundation (ETF) contributes, in the context of EU external relations policies, to human capital development, defined as work that contributes to the lifelong development of individuals' skills and competences through the improvement of vocational education and training systems.

Structural reforms in VET are being supported through the European Social Fund. International cooperation, including mobility of VET learners and staff, is being financed through the Erasmus + programme.

Source: European Commission 2018a adapted

Within the Copenhagen process, European cooperation in VET has been based on voluntary commitment and has become a catalyst for peer learning and modernising VET in many EU Member States, EEA and candidate countries. The overall goal has been to improve lifelong learning and mobility and help create a single labour market through common European instruments and principles ${ }^{7}$ that help make people's knowledge, skills and competences better visible and easier to compare, understand and recognise. These promote links between and combinations of different types and levels of education and training (see Table 1).

informing on VET benefits. In the 1960s, ensuring transition from general education to VET, progression to 'higher level activities', and career information and guidance also featured on the agenda (Cedefop, 2004). $7 \quad$ Articles 165 on encouraging cooperation between Member States for 'the development of quality education' and 166 on 'a vocational training policy' of the Lisbon Treaty. 
Table 1.

Common European instruments and principles developed under the Copenhagen process

\begin{tabular}{|c|c|}
\hline $\begin{array}{l}\text { Common European } \\
\text { instruments }\end{array}$ & \\
\hline $\begin{array}{l}\text { European qualifications } \\
\text { framework (EQF) }\end{array}$ & $\begin{array}{l}\text { Helps compare qualifications throughout Europe to support } \\
\text { lifelong learning and educational and job mobility }\end{array}$ \\
\hline $\begin{array}{l}\text { European credit system for } \\
\text { VET (ECVET) }\end{array}$ & $\begin{array}{l}\text { Helps validate, recognise and accumulate work-related skills } \\
\text { and knowledge acquired during a stay in another country or } \\
\text { in different situations, so that these experiences contribute to } \\
\text { vocational qualifications }\end{array}$ \\
\hline $\begin{array}{l}\text { European quality assurance } \\
\text { framework for VET (EQAVET) }\end{array}$ & $\begin{array}{l}\text { Helps countries develop, improve, guide and assess the qual- } \\
\text { ity of their VET systems and develop quality management } \\
\text { practices }\end{array}$ \\
\hline Europass & $\begin{array}{l}\text { A portfolio of documents (Curriculum Vitae, European skills } \\
\text { passport, Language passport, Europass mobility, Diploma } \\
\text { supplement and Certificate supplement) to support job and } \\
\text { geographical mobility by enabling people to present quali- } \\
\text { fications and skills in a standard format understandable to } \\
\text { employers throughout Europe }\end{array}$ \\
\hline \multicolumn{2}{|l|}{$\begin{array}{l}\text { Common principles and } \\
\text { guidelines }\end{array}$} \\
\hline Guidance and counselling & $\begin{array}{l}\text { Strengthens the role of lifelong guidance in developing Eu- } \\
\text { ropean policies for education, training and employment. } \\
\text { It addresses four priority areas: career management skills, } \\
\text { access to services, quality of guidance provision and policy } \\
\text { cooperation }\end{array}$ \\
\hline $\begin{array}{l}\text { Identification and validation } \\
\text { of non-formal and informal } \\
\text { learning }\end{array}$ & $\begin{array}{l}\text { Sets out common principles to encourage and guide develop- } \\
\text { ment of high quality, trustworthy approaches and systems to } \\
\text { identify and validate non-formal and informal learning }\end{array}$ \\
\hline
\end{tabular}

Source: updated from Cedefop 2010

Within the Copenhagen process, while up to 2010, priorities had been adjusted every two years ${ }^{8}$, a new approach was adopted in the 2010 Bruges Communiqué (Council of the European Union and European Commission, 2010). There, ministers of the EU-28+, candidate countries and European social partners set out strategic objectives for 2020, known as ET 2020 (Council of the European Union, 2009a) (see Box 3), combining them with shorter-term priority areas (22 actions known as short-term deliverables, STDs) to work from 2011-2014. At their 2015 meeting in Riga, following a review of this first cycle, they decided to focus on five main areas in their work towards the 2020 objectives for VET. These are referred to as medium-term deliverables, MTDs (see Box 4.)

8 Communiqués of Maastricht (2004), Helsinki (2006), Bordeaux (2008) and Bruges (2010). 
Box 3.

European benchmarks by 2020 set under ET 2020

- At least $95 \%$ of children should participate in early childhood education.

- Fewer than $15 \%$ of 15 -year-olds should be under-skilled in reading, mathematics and science.

- The rate of early leavers from education and training aged 18-24 should be below $10 \%$

- At least $40 \%$ of people aged 30-34 should have completed some form of higher education.

- At least $15 \%$ of adults should participate in learning.

- At least $20 \%$ of higher education graduates and $6 \%$ of $18-34$ year-olds with an initial vocational qualification should have spent some time studying or training abroad.

- The share of employed graduates (aged 20-34 with at least upper secondary education attainment and having left education 1-3 years ago) should be at least $82 \%$.

Source: Council of the European Union (2009a)

Box 4.

Riga medium-term deliverables (MTDs)

MTD1. Promote work-based learning in all its forms, with special attention to apprenticeships, by involving social partners, companies, chambers and VET providers, as well as by stimulating innovation and entrepreneurship.

MTD2. Further develop quality assurance mechanisms in VET in line with the EQAVET recommendation and, as part of quality assurance systems, establish continuous information and feedback loops in initial VET and continuous VET systems based on learning outcomes.

MTD3. Enhance access to VET and qualifications for all through more flexible and permeable systems, notably by offering efficient and integrated guidance services and making available validation of non-formal and informal learning.

MTD4. Further strengthen key competences in VET curricula and provide more effective opportunities to acquire or develop those skills through initial VET and continuous VET.

MTD5. Introduce systematic approaches to, and opportunities for, initial and continuous professional development of VET teachers, trainers and mentors in both school and work-based settings

Source: Council of the European Union; European Commission, 2015a

The five Riga MTDs, although broader in scope, relate to most of the strategic objectives and embrace many of the issues addressed by the Bruges 2011-14 short-term deliverables. They provide a framework for continuity in countries' policy developments from 2015-2020. This continuity between deliverables and strategic objectives requires revising, adapting and complementing deliverables, considering the evolution of the VETrelated policy agenda. Thus, under the Riga Conclusions, Member States continued the reform process they had previously engaged in, expanding and complementing measures, but also devising new types of initiatives. Riga included for example a deliverable that was not part of the previous cycle, but is essential to achieve the others: the systematic professional development of teachers, trainers and mentors (MTD 5).

In this perspective, continuity within the Copenhagen process was not just seen in terms of deliverables (actions) and their numbers but maintaining the momentum of what started in 2002 as a strategy for closer cooperation in VET and taking it further: 
building on the 2020 vision to make VET a first-class choice for all learners within a lifelong learning span. This entails increasing VET attractiveness and quality; ensuring that VET pathways reach into higher education levels in all countries participating in the Copenhagen process; and expanding mobility measures. Under this European framework of cooperation, social partners, VET providers and other stakeholders need to have an active role in development and implementation. Evidence furnished by the latest Cedefop monitoring exercise and research suggest that cooperation has gone deeper across the Member States, EEA and candidate countries.

Box 5 .

The European semester ${ }^{9}$

Since 2010, in parallel to their joint work on VET, the EU-28 have been working on their national reform programmes, which the European Commission analyses annually to follow up their commitment to the European goals (European semester). For the candidate countries, the EU's economic governance process, light European semester, is the key political framework for reforms. Progress under Riga is picked up when governments submit annual updates on their national economic reform programmes. As a result, Member States and candidate countries may receive recommendations to address VET-related challenges. Subsequently, they report on their measures and progress achieved. Such country-specific recommendations have, for instance, referred to apprenticeships, reducing early leaving from education and training, improving educational attainment of disadvantaged groups or reforming teacher and trainer training.

\subsection{EU policies and initiatives addressing VET}

Over the last years, several EU level policy initiatives and processes have been undertaken to reform VET systems and progress towards the five Riga medium-term deliverables (MTDs).

\section{MTD1. Promote work-based learning in all its forms}

The European alliance for apprenticeships launched in 2013 (European Commission et al., 2013), aims to help strengthen quality, supply and image of apprenticeships and engage countries and stakeholders. The alliance is underpinned by a joint declaration by the European Commission, the Lithuanian Presidency of the EU and the European social partners (European Commission et al., 2013) and supported by a Council declaration (Council of the European Union, 2013a). In addition, the 2014-15 working group on VET, set up within the ET 2020 framework composed by social partners, representatives of the Member States, Cedefop and the ETF focused specifically on apprenticeships and other forms of work-based learning and developed relevant guiding principles (European Commission, 2016a). A European framework for quality and effective apprenticeships was also adopted in March 2018, supporting work on this MTD (Council of the European Union, 2018a).

9 https://ec.europa.eu/info/business-economy-euro/economic-and-fiscal-policy-coordination/eueconomic-governance-monitoring-prevention-correction/european-semester_en 


\section{MTD2. Further develop quality assurance mechanisms in VET and establish continuous information and feedback loops}

Concerns that skills mismatch will become more prominent in European labour markets due to the economic crisis and technological changes, and that demographic ageing may lead to a progressive reduction in labour supply call for a better understanding of how graduates fare on the labour market. A recommendation on tracking graduates (Council of the European Union, 2017b), as proposed by the comprehensive new skills agenda ${ }^{10}$ (European Commission, 2016b), aims not only to ensure better qualitative and quantitative data but also to feed them back to VET policy and provision, guidance services and learners. This reinforces the work on feedback loops and is closely linked to the use of the European Quality Assurance in Vocational Education and Training (EQAVET) outcome indicators ${ }^{11}$. This makes tracking of graduates one of the key tools for ensuring the quality of vocational education (ETF, 2018).

\section{MTD3. Enhance access to VET and qualifications for all}

Getting people (back) into work and promoting equality, inclusion and solidarity has been among the main threads of EU policy in recent years to counteract the effects of the economic crisis. Numerous policy documents have addressed this challenge over the last period. The European Pillar of Social Rights (European Commission, 2017a and 2017b) has laid down the principles for building a more inclusive and fairer Union. The right to quality and inclusive education, training and lifelong learning is the first of the 20 principles of the social pillar. It refers explicitly to continuing education, apprenticeships or traineeships for young people ${ }^{12}$. The 'social scoreboard', developed to track Member States' performance and inform the European Semester, includes the early leaving and NEET indicators.13.

An ET 2020 working group on "Common values and inclusive education" was set up by the European Commission to support the follow-up to the Paris Declaration of 201514. The thematic group (operated during 2018-2020) addressed four main issues15 promoting inclusive education for all learners.

Several specific EU initiatives and Council Recommendations have been undertaken, including the Youth Guarantee (Council of the European Union, 2013b), the Recommendation on upskilling pathways (Council of the European Union, 2016a), the

10 This comes with a comprehensive policy package addressing three main aims: to improve the quality and relevance of skills formation; make skills and qualifications more visible and comparable; and improve skills intelligence and information for better career choices. The European Commission has invited Member States to develop national skills strategies and monitors progress (European Commission, 2016b).

11 https://www.eqavet.eu/EU-Quality-Assurance/For-VET-Providers/monitoring-your system/ evaluation/EQAVET-Indicators

12 http://ec.europa.eu/social/main.jsp?catId=1226\&langId=en

13 https://composite-indicators.jrc.ec.europa.eu/social-scoreboard/

14 Informal meeting of European Union education ministers declaration on Promoting citizenship and the common values of freedom, tolerance and non-discrimination through education, Paris, 17 March 2015. https://ec.europa.eu/assets/eac/education/news/2015/documents/citizenship-educationdeclaration_en.pdf

15 These are: Promote common values and intercultural competences, including citizenship education and digital citizenship; Promote inclusive education for all learners; Promote a European dimension of education and training; Support education staff in dealing with diversity and create an open climate in learning settings. 
revised EQF recommendation (Council of the European Union, 2017a) and the Council recommendation on automatic mutual recognition, adopted in November 2018 (Council of the European Union, 2018a). Further, the ErasmusPro initiative, aimed to support long-duration mobility of VET learners and apprentices, has been introduced in 2017.

\subsubsection{MTD4. Further strengthen key competences in VET curricula}

People need to be continuously updating their skills. This is one of the main messages of the new skills agenda ${ }^{16}$ (European Commission, 2016b) having important policy implications for governments who need to create adequate pathways and give learning opportunities for a large share of Europeans in the coming years: Cedefop estimate is that about $46 \%$ the adult population in Europe is potentially in need of upskilling and reskilling, since they present either low education, low digital skills, low cognitive skills or are medium- to high-educated at risk of skill loss and obsolescence (Cedefop, 2020a).

Eight key competences for lifelong learning were endorsed at European level in 2006 (European Parliament and Council of the EU, 2006). They complement but also somewhat overlap with similar approaches proposed by international organisations: basic skills (Cedefop, 2014) and new basic skills (Council of the European Union, 2002) needed to live in today's knowledge society; "fundamental basic skills" (language, literacy, numeracy and ICT) and "transversal key competences" such as initiative-taking and cultural awareness (Council of the European Union, 2010); OECD's key competences (OECD 2005); ILO's core competences (ILO 2009); and 21st century skills (Dede, 2009). A new recommendation on key competences for lifelong learning was adopted on 22 May 2018 (Council of the European Union, 2018b) refining the eight key competences needed for work and life fulfilment: lliteracy, multilingualism, numerical, scientific and engineering skills, digital and technology-based competences, interpersonal skills, and the ability to adopt new competences, active citizenship, entrepreneurship, cultural awareness and expression.

\subsubsection{MTD5. Initial and continuous professional development of VET teachers and trainers}

More work-based learning and apprenticeships, more emphasis on key competences, new and more heterogeneous target groups and digitalisation are all putting more demands on teachers and trainers. The central role of teachers in VET schools and trainers/mentors in companies has been recognised in the policy discourse and policy documents for quite some time. The Riga conclusions (2015) called for systematic approaches to and opportunities for initial and continuing professional development (CPD) of VET teachers and trainers to fulfil their role, including digital skills and innovative teaching methods (MTD 5). The European Framework for Quality and effective apprenticeships (Council of the European Union, 2018a) stressed that to provide quality support to learners, teachers and trainers should be supported to update their skills, knowledge and competences to train using the latest teaching and training methods and in line with the labour market needs.

A previous ET 2020 Working Group on VET operating from 2016-2018 aimed to support countries' work on professional development of teachers and trainers. Representatives

16 This comes with a comprehensive policy package addressing three main aims: to improve the quality and relevance of skills formation; make skills and qualifications more visible and comparable; and improve skills intelligence and information for better career choices. The European Commission has invited Member States to develop national skills strategies and monitors progress (European Commission, 2016b). 
from different European countries agreed in 12 policy pointers (European Commission, 2018) developed from the key issues identified by the Working Group. These policy pointers have a vital role to play in successfully supporting teachers and trainers into four topics: specifying the roles and responsibilities of teachers and trainers in VET systems; strengthening the professional development of teachers and trainers; equipping teachers and trainers for key challenges; and fostering collaboration to support their work. At the time of writing this paper, a new Council Conclusions on European teachers and trainers for the future are under preparation expected to be adopted in March 2020.

\subsection{National responses to European initiatives}

Cedefop's report on the 2010-14 Bruges cycle (Cedefop, 2015) detailed how the Copenhagen/Bruges process had an impact on national VET policy and strategy in all countries, though depending on their respective starting points. More than 20 countries had introduced legislative or policy changes to adapt or introduce new programmes, pathways and qualifications. For some countries, the Bruges Communiqué provided a menu to prioritise or choose the most relevant themes. In those with strong VET traditions, Bruges had stimulated cooperation and encouraged policy learning.

In many cases, policies and measures were not new. Actually, for the majority of STDs countries extended, amended and complemented a series of policy initiatives that were already in place by 2010 .

By 2015, taking the situation in 2010 as a baseline for their way towards the Bruges/ET 2020 objectives, Cedefop's reporting exercise (2015) identified four clusters of countries:

a) continuous developers, with many measures of the Bruges package already in place by 2010, followed by significant developments in the 2010-14 period;

b) early developers, with many measures already in place by 2010 and some developments afterwards;

c) recent implementers, with some measures already in place by 2010 and significant developments in 2010-14;

d) modest developers, showing slow progress.

Thus, countries did not start from the same point to address the Riga Conclusions in 2015. While for some countries, the work on VET was part of a natural evolution, other countries needed to strengthen VET's role and its relevance. Their developments also responded to ad-hoc challenges, for instance in countries that were faced with large numbers of third country nationals arriving in the context of the refugee crisis.

According to the latest Cedefop monitoring exercise (Cedefop forthcoming, 2020d) ${ }^{17}$, overall, with small variations, participating countries had selected apprenticeships and work-based learning as the top priority under Riga followed by access to VET and qualifications for all; teacher and trainer training; key competences and quality and feedback loops followed to lesser extent.

The high attention paid to making apprenticeships and work-based learning attractive for learners and employers (MTD1) has been a strong common trend among all participating countries. Most actions focused on apprenticeships at secondary level, either preparing the grounds, legal frameworks or updating rules and principles and qualification structures. Countries with mainly school-based VET have worked to expand learning opportunities in enterprises (Cedefop forthcoming, 2020d).

17 Findings presented during the $17^{\text {th }}$ ReferNet annual plenary meeting, 6-7 February 2020, Cedefop Thessaloniki. 
As regards countries' work on quality assurance for VET (MTD2), candidate countries focused on quality assurance approaches at system and provider level, making use of the EQAVET framework, while the EU-28+ developed their approaches further. All worked to strengthen skills anticipation and feedback loops. Despite improvements, systematic use of outcome indicators and graduate tracking still seem to be weak spots at European level (Cedefop forthcoming, 2020d).

As regards enhancing access to VET and qualifications (MTD3), countries proceeded with structural changes to make VET pathways more flexible, broaden access to VET and improve progression opportunities. However, coordinated strategic approaches have not yet been frequent. Actions focused on youth, on improving training opportunities for the low-skilled (Cedefop forthcoming, 2020c,), unemployed and newly arrived migrants. While guidance services and tools have been stepped up, comprehensive approaches remain an area for improvement. Countries have also reinforced their work on validating non-formally and informally acquired skills and recognition of qualifications or prior formal learning (Cedefop forthcoming, 2020d).

All efforts aiming to support the transition between education levels and types of education offering flexible learning pathways have contributed, among other, to lowering considerably the rates of early leaving from education and training (ELET) ${ }^{18}$ to 10.6 $\%$ as of $2018^{19}$. Towards this strategic objective, Cedefop has taken a leading role with a view to providing practitioners and policy-makers with practical support. Cedefop VET toolkit for tackling early leaving ${ }^{20}$, launched in May 2017, is designed to help young people at risk of becoming early leavers to remain in education and training and help early leavers to reintegrate into education or training and the labour market (Psifidou, 2019).

To offer the right combination of skills to all learners countries have been working to strengthening key competences in learning-outcomes based VET curricula (MTD4). In most cases, they have focused on language and digital skills, while references to soft competences are fewer. Systematic curriculum reforms still concern mainly initial VET and in general seem to have not marked significant progress. Actions to reinforce key competences include defining national lists of key competences or developing tools to assist the mapping of key competences; setting up strategies, programmes and action plans; updating curricula, etc. (Cedefop forthcoming, 2020d).

According to Cedefop's monitoring data on Riga medium-term deliverables in 2015-19 (Cedefop forthcoming, 2020d), measures in support to the development of VET teaching and training professions (MTD5) have addressed VET school teachers and trainers more than in-company trainers and mentors. Since several countries face the challenge of an ageing teaching staff, attention was given more on improving status and career opportunities rather than making the profession more attractive and improving initial training ${ }^{21}$. More generally, continuous professional development of school staff has attracted more attention than professions' entry requirements and procedures ${ }^{22}$.

18 The indicator 'early leavers from education and training (ELET)' (also named 'early school leavers') refers to people aged 18-24 who obtained no more than a lower secondary diploma and are not enrolled in further education or training. European Commission (2019). Education and training monitor, 2019, p. 51

19 Eurostat, EU Labour Force Survey, 2018 in European Commission (2019). Education and training monitor, 2019, p.51

20 www.cedefop.europa.eu/TEL-toolkit

21 Actions under this aim included (re)defining entry requirements and/or entry procedures; upgrading/updating pre-service and/or initial in-service teacher training programmes and introducing/ upgrading measures to attract new teachers, including attracting experts from the world of work.

22 Priorities have been the introduction/update of requirements, programmes and courses; the development of innovative learning approaches and support measures; opportunities for teacher visit / traineeship / working in company and for cooperation with in-company mentors; career development 
Finally, policies to structure the process of accessing to mentoring and training roles in company has received growing attention also in connection with the need for accompanying the reforms of apprenticeship and other forms of workplace-based learning. Actions in this area have mainly consist in re/defining the requirements to become a mentor/trainer, developing specific training programmes, and introducing/updating measures to increase the availability of qualified mentors/trainers in companies.

During this period, the EU level cooperation in the field of VET has been mainly realised through four types of activities, supported where applicable, by funding from Erasmus+ and European Social Fund (see Box 6):

- Activities to support the implementation of Council Recommendations: organised notably through specific stakeholders' groups and underpinned by targeted funding and mutual learning (networks, users' groups, dedicated calls for proposals).

- Policy initiatives in the area of VET: notably the European Alliance for Apprenticeship and the European Vocational Skills Week.

- Mutual learning activities: notably ET 2020 working groups, peer reviews and other peer learning activities (including Cedefop and ETF events).

- Monitoring of progress: notably by Cedefop and ETF monitoring VET policy; ET Monitor; ET 2020 benchmarks or IVET Mobility Scoreboard.

Box 6.

Erasmus+ and European Social Fund

Erasmus + Programme: has an (initial) overall indicative financial envelope of 14.774 billion EUR. Of these, almost $€_{3}$ Billion are assigned to VET over the period 2014-2020. Every year around 130.000 VET learners and 20.000 VET staff benefit from mobility actions. In addition, almost 500 VET projects are financed under Strategic partnerships every year under Erasmus+. The programme also finances other activities relevant such as Sector Skills Alliances (including sectoral Blueprint) or targeted calls for policy reform.

The European Social Fund (ESF): is an important financial lever for VET. For the programming period 2014-2020, the ESF has a thematic objective (TO10) entitled "investing in education, training and vocational training for skills and life-long learning" which assigns €6,8 Billion for "Improving the labour market relevance of education and training systems, facilitating the transition from education to work, and strengthening vocational education and training systems and their quality, including through mechanisms for skills anticipation, adaptation of curricula and the establishment and development of work-based learning systems, including dual learning systems and apprenticeship schemes".

Source: adapted from European Commission, 2018a.

To summarise, evidence furnished by Cedefop monitoring exercise and comparative research shows that participating countries in the Copenhagen process have taken considerable action over the last decade on all five MTDs defined by the Riga Conclusions. Type and speed of action vary by MTD and from one VET system to another, depending on country context and starting point. This evidence also signals continuity in countries' work. The Bruges impetus has been maintained, and not only because the Riga opportunities for teachers, including in terms of reaching leadership positions; as well as support to VET school leaders and their professional development. 
deliverables build on its objectives and the previous deliverables. Countries' priorities among the deliverables, policy actions and focus to address them demonstrate continuity of their policies and strategies over a longer period. Their work on apprenticeships and work-based learning, as well as on tackling early leaving from education and training which often pre-dates Bruges, are only two of many other examples. This also reflects long-term commitment, strengthened cooperation and peer learning among European countries for individual solutions. All these are core values underpinning the Copenhagen process.

\section{Overall trends and challenges ahead}

Since there is no single VET system in Europe but a number of very diverse national systems, it is not straightforward to say in which policy areas progress has been made (or not) in achieving the VET policy priorities. At an aggregate EU level, an outcome oriented approach based on the analysis of main trends in VET attractiveness and participation can help to provide some indications about areas in which concentrate policy efforts in the years to come.

\subsection{Trends in VET}

Initial Vocational Education and Training (IVET) firmly remains one of two key pathways for young people to enter the labour market. Despite the narratives about participation in IVET, about $50 \%$ of young Europeans still participate in IVET and get a vocational qualification at upper secondary level ${ }^{23}$.

Evidence is that holding a vocational qualification is a good way to prepare young people for entering the labour market. At a time when more and more European employers claim they cannot find people with the right skills to fill their vacancies, $80 \%$ of young people with a medium level vocational qualification are in employment as compared to $57 \%$ of their pairs with a lower level of education and $74 \%$ of graduates with upper secondary general qualification ${ }^{24}$. While systematic data is not available at the EU level, evidence is that young people holding a VET qualification also get higher salaries than their counterpart with general orientation; and that labour market outcomes of vocational pathways are even more apparent when as IVET qualification is obtained through work-based learning, and particularly apprenticeships.

European citizens are generally well aware of the favourable outcomes of vocational learning. As Cedefop opinion survey on VET clearly shows (Cedefop, 2017c), Europeans highly value upper secondary VET as a way to find jobs, strengthen the economy, help reduce unemployment and foster social inclusion. In spite of this, in too many EU Member States, citizens surveyed by Cedefop still consider VET as a second choice when compared to general education. One of the possible explanations of this paradox is that, in the absence of well-functioning lifelong learning systems, providing high quality and inclusive continuing training, comparative advantages of IVET tend to dissipate over time.

Actually, vocational learning plays a growing role also in the continuing professional development of adults. Data from the Continuing Vocational Training Survey shows that employers' sponsored training increased significantly over the time between two latest

23 Cedefop's calculations based on Eurostat, UOE data collection on formal education.

24 All employment figures refer to young people aged 20-34 not in further education or training. Cedefop (2020b). 
successive surveys ${ }^{25}$ (from $49.7 \%$ in 2005 to $60 \%$ in 2015) with the biggest increase registered among small companies $(\sim 11 \mathrm{pp})^{26}$. On the other hand, Cedefop estimate, based on CVTS and AES surveys, is that non-formal training undertaken for job-related purposes and sponsored by employers represents about $80 \%$ of total participation of adults to learning, either formal or non-formal. The low participation of people not in employment or not supported by their employers, contributes to explain why the EU's (modest) target of $15 \%$ adult participation will likely not be met by 2020, and, importantly, its uneven progress across different components of the population. While lifelong learning policies are working comparatively well for well-educated and those with higher socioeconomic status, they continue to struggle to reach out precisely those who are most in need of learning, such as low-educated and low-skilled adults more generally.

Against this background, while enhancing quality and responsiveness of initial VET to forward-looking societal and educational challenges remains an important area of work, the full development of high quality and inclusive continuing VET systems seem to be the new priority for the years to come.

\subsection{Some of the challenges ahead}

Drawing from Cedefop extensive research, monitoring and policy analysis, as well as its experience in supporting policy learning across MSs, it is possible to identify some emerging challenges and patterns of VET in the EU as suggested points of reflection and, most importantly, for shaping future policy action.

\subsubsection{Expansion and diffusion of structured work-based learning in IVET}

The European Framework for Quality and Effective Apprenticeships ${ }^{27}$ is an important milestone on the way to build apprenticeships that lead to recognised qualifications schemes based on common agreed quality criteria. However, Cedefop analysis shows that the diffusion of work-based learning structured approaches, and particularly of apprenticeships over the last decade has been accompanied by an emerging model in Europe in which apprenticeship is seen as a mode of learning rather than a real system with its own governance, programmes and qualifications (Cedefop, 2018). This trend contains an important challenge for the EU MSs to address when looking at the future of their IVET systems. While apprenticeship as a mode of learning may allow national VET systems more flexibility and responsiveness to the needs of individual employers and learners, in this approach the educational and training function of apprenticeships risk to be overshadowed by the employment function and therefore undermine the value and identity of apprenticeships (Rustico L., David R. and Ranieri A., 2020).

\subsubsection{Reskilling and up-skilling of all adults through continuing training and adult learning}

In a fast changing and uncertain labour market it is essential to make sure that the European workforce doesn't get 'lost in transition'. Quality IVET, and especially apprenticeship, connect people with the labour market and perform better in youth employment.

$25 \quad$ CVTS targets employers sponsored training in enterprises with at least 10 employees across particular industry sectors.

26 Eurostat, CVTS dataset, accessible here: https://ec.europa.eu/eurostat/web/microdata/ continuing-vocational-training-survey. CVTS targets employers sponsored training in enterprises with at least 10 employees across particular industry sectors.

27 https://eur-lex.europa.eu/legal-content/EN/TXT/PDF/?uri=CELEX:32018Ho502(01)\&from=EN 
However, evidence is that comparative advantages of IVET tend to dissipate over time unless it is integral part of high quality and inclusive lifelong learning systems. Moreover, the growing awareness of the potential impact of current economic, technological, and societal trends call for a new focus on continuing vocational training policy as well as effective strategies for upskilling and reskilling of all adults carefully designed to target specific priority groups (such as the low-skilled, the vulnerable, workers in SMEs). To address these challenges, the Council Recommendation on Upskilling Pathways (Council of the European Union, 2016a), calls on Member States to facilitate access to quality learning opportunities to adults with low levels of skills through coordinated approaches including the three steps of skills assessment, tailored learning offer and validation and recognition of the skills acquired. However, devising an effective adult learning system still seems to be a distant goal in many EU Member States. In line with the first principle of the European Pillar of Social Rights (European Commission, 2017a and 2017b), the mission to provide quality, inclusive and financially sustainable lifelong learning system as a right for all adults in Europe is widely believed to be the main challenge for the years to come.

\subsubsection{Guidance, validation and financing as preconditions for effective vocational lifelong learning systems}

Making a European area of lifelong learning a reality is the long-standing goal of European policy in education and training. However, devising coordinated vocational learning systems and quality training opportunities for adults may not be sufficient without having a full understanding about how motivate and attract people to learning. On the one hand, the rapidly changing developments in technology and work organisation make it difficult for people to understand what is the right education and training choice to ensure they have the best possible chance of succeeding also in the medium- long-run. On the other hand, navigating through work and learning life may be difficult especially for adults who have to balance their participation in learning with family responsibility. In this perspective, EU and national strategies and policies growingly emphasise the importance of capacitation in individual career development support and flexible financial and nonfinancial support to learning. The device of a coordinated set of mechanisms, tools and interventions and ensuring synergies between the different areas of policy remains one of the challenges left untaken in most Member States.

\section{Concluding remarks}

This paper is written at a time that the current strategic framework for European cooperation in education and training (ET 2020) and the Bruges-Riga cycle come to an end, while discussion on VET European strategy beyond 2020 is still under way.

A first firm step in this policy discussion is the formal opinion prepared by the European Advisory Committee in Vocational Training (ACVT) in December 2018 (European Commission, 2018a). With a view to the future of VET, the ACVT points to considerable challenges arising from the changing and increasing skills demands, coupled with economic, demographic and technological developments. At the same time, these challenges are seen as powerful opportunities for innovative responses and reform in EU Member States. In broad terms, European VET systems are expected build on the process initiated in 2002 and deliver excellent and inclusive education and training 
by 2030 working on three core elements (European Commission, 2018a, p.6): a) foster acquisition of skills, competences and qualifications which ensure employability, adaptability, personal development and active citizenship of individuals b) provide accessible, attractive, valued and innovative quality assured provision for all, and c) device integrated, responsive, diversified and quality assured VET systems underpinned by governance, funding and guidance which foster excellence, inclusion, effectiveness and shared responsibility.

In this perspective, the strategic focus set out with the Riga Conclusions in 2015 still seems to hold true today, especially when it comes to ensuring VET paths to qualifications for all, providing relevant skills sets by reinforcing work-based learning, key competences and skills intelligence, as well as placing emphasis on teachers' and trainers' competence development. Importantly, there are clear indications that policy efforts supporting the European strategy on VET has produced positive impacts in most European countries to enhance quality and inclusiveness of VET.

On the other hand, a more ambitious and forward-looking approach to VET reforms seems necessary to address the future economic and societal challenges. As highlighted by the ACVT Opinion, VET should prove its ability to prepare people not only for existing jobs, but also for future employment and job creation. Emerging new technologies and new work organisational formats should be captured faster through skills anticipation systems and translated into VET provision in terms of needed skills, curricula and qualifications. And, at the same time, VET provision should be able to combine the specialised skills demanded in the short term with the key competences needed to build the European societies of the future.

This leads to what is perhaps the challenge of all challenges: how to improve effectiveness of strategic coordination, partnerships cooperation, and policy integration in the design and implementation of European VET policy. Preparing people for the future effectively requires the structural involvement of a variety of stakeholders, as well as the ability to look at VET policies not in isolation but as a component of a broad range of different policy areas.

Sometimes the unique multilevel and multi-stakeholder structure of European VET may appear overly complex and bear the risk that too much can be 'lost in transaction'. In fact, the contrary is true.

What is apparent today, more than ever before, is that the European institutional and policy framework represents the real strength for Member States to focus on the big picture over the long term and make the most of the opportunities that an enhanced cooperation among national systems may offer to improve the overall performance, quality and attractiveness of VET in Europe.

\section{References}

Cedefop (2004). A history of vocational education and training in Europe. From divergence to convergence. The European Journal 'Vocational Training, No. 32, May-August 2004II, Cedefop. Retrieved June 2, 2020 from: https://www.cedefop. europa.eu/files/32-en.pdf

Cedefop (2010). Briefing Note: Learning to change: vocational education and training reform 2002-1O. December. Retrieved June 2, 2020 from: https://www.cedefop. europa.eu/node/11714 
Cedefop (2012). Trends in VET policy in Europe 2010-12. Progress towards the Bruges communiqué. Working paper No 16, Luxembourg: Publications Office of the European Union.

Cedefop (2014). Terminology of European education and training policy: a selection of 130 key terms. Second edition. Luxembourg: Publications office. Retrieved June 2, 2020 from: http://www.cedefop.europa.eu/el/publications-and-resources/ publications $/ 4117$

Cedefop (2015). Stronger VET for better lives: Cedefop's monitoring report on vocational education and training policies 2010-14. Luxembourg: Publications Office. Cedefop reference series; No 98. Retrieved June 2, 2020 from: http://www. cedefop.europa.eu/el/publications-and-resources/publications/3067

Cedefop (2016). Leaving education early: putting vocational education and training centre stage. Volume II: evaluating policy impact. Luxembourg: Publications Office. Cedefop research paper; No 58. Retrieved June 2, 2020 from: http://dx.doi. org/10.2801/967263

Cedefop (2017a). The changing nature and role of vocational education and training in Europe. Volume 1: conceptions ofvocational education and training: an analytical framework. Luxembourg: Publications Office. Cedefop research paper; No 63. Retrieved June 2, 2020 from: http://www.cedefop.europa.eu/en/publicationsand-resources/publications/5563

Cedefop (2017b). The changing nature and role of vocational education and training in Europe. Volume 2: Results of a survey among European VET experts. Luxembourg: Publications Office. Cedefop research paper; No 64. Retrieved June 2, 2020 from: http://dx.doi.org/10.2801/548024

Cedefop (2017c). Cedefop opinion survey on vocational education and training in Europe. Luxembourg: Publications Office. Cedefop research paper; No 62. Retrieved June 2, 2020 from: http://www.cedefop.europa.eu/en/publicationsand-resources/publications/5562

Cedefop (2018). Apprenticeship schemes in European countries: a cross-nation overview.Luxembourg: Publications Office of the European Union.

Cedefop (2019). Cedefop's recast Founding Regulation came into force in February 2019 (Regulation (EU) 2019/128 of the European Parliament and of the Council of 16 January 2019 establishing a European Centre for the Development of Vocational Training (Cedefop) and repealing Council Regulation (EEC). No 337/75. Retrieved June 2, 2020 from: https://eur-lex.europa.eu/legal-content/ EN/TXT/?uri=CELEX\%3A32019Ro128

Cedefop (2020a). Empowering adults through upskilling and reskilling pathways. Volume 1: adult population with potential for upskilling and reskilling. Retrieved June 2, 2020 from: https://www.cedefop.europa.eu/files/3081_en.pdf

Cedefop (2020b). On the way to 2020: data for VET policies - Indicator Overviews. 2019 update. Retrieved June 2, 2020 from: https://www.cedefop.europa.eu/ files/5576_en.pdf 
Cedefop forthcoming (2020c). Empowering adults through upskilling and reskilling pathways. Volume 2. Developing coordinated and coherent approaches to upskilling pathways for adults. Cedefop analytical framework for developing upskilling pathways for low-skilled adults.

Cedefop forthcoming (2020d). Findings from Cedefop 2020 (forthcoming). Enhancing European cooperation in VET: outcomes of the Riga round. Progress in common priorities for 2015-20 presented at 17th ReferNet annual plenary meeting, 6-7 February 2020, Cedefop, Thessaloniki.

Council of the European Union (2002). Council resolution of 27 June 2002 on lifelong learning. Official Journal of the European Union, C 163, 9.7.2002, pp. 1-3. Retrieved June 2, 2020 from: https://eur-lex.europa.eu/legal-content/EN/ TXT/?uri=uriserv:OJ.C_.2002.163.01.0001.01.ENG\&toc=OJ:C:2002:163:TOC

Council of the European Union (2009a). Council conclusions of 12 May 2009 on a strategic framework for European cooperation in education and training ('ET 2020').

Council of the European Union (2009b). Recommendation of the European Parliament and of the Council of 18 June 2009 on the establishment of a European quality assurance reference framework for vocational education and training. Official Journal of the European Union, C 155, 8.7.2009, pp. 1-10. Retrieved June 2, 2020 from: https://eur-lex.europa.eu/legal-content/EN/TXT/ $\mathrm{PDF} /$ ?uri=CELEX:32009Ho708(o1)\&qid=1591342947146\&from $=\mathrm{EN}$

Council of the European Union (2013a). Council declaration on a European alliance for apprenticeships. Brussels, 18 October 2013. Retrieved June 2, 2020 from: http:// register.consilium.europa.eu/doc/srv?l=EN\&f=ST\%2014986\%202013\%20INIT

Council of the European Union (2013b). Council recommendation on establishing a youth guarantee. Official Journal of the European Union, C120, 26.4.2013, pp. 1-6. Retrieved June 2, 2020 from: https://eur-lex.europa.eu/legal-content/EN/ ALL/?uri=CELEX\%3A32013Ho426\%2801\%29

Council of the European Union (2016a). Councilrecommendation of 19December 2016 on upskilling pathways: new opportunities for adults. Official Journal of the European Union,C484,24.12.2016,pp.1-6. RetrievedJune2,2020from:http://eur-lex.europa. eu/legal-content/EN/TXT/PDF/?uri=CELEX:32016H1224(01)\&from=EN

Council of the European Union (2016b). Council resolution on a new skills agenda for an inclusive and competitive Europe. Official Journal of the European Union, C 467, 15.12.2016. Retrieved June 2, 2020 from: http://eur-lex.europa.eu/legalcontent/EN/TXT/PDF/?uri=CELEX:32016G1215(01)\&from=EN

Council of the European Union (2017a). Council recommendation of 22 May 2017 on the European qualifications framework for lifelong learning and repealing the recommendation of the European Parliament and of the Council of 23 April 2008. Official Journal of the European Union, C 189, 15.6.2017, p1528. Retrieved June 2, 2020 from: http://eur-lex.europa.eu/legal-content/EN/ TXT/?uri=CELEX:32017Ho615(01) 
Council of the European Union (2017b). Council recommendation of 20 November 2017 on tracking graduates. Official Journal of the European Union, C 423, 9.12.2017. Retrieved June 2, 2020 from: https://eur-lex.europa.eu/legal-content/EN/ TXT/?uri=CELEX\%3A32017H1209\%2801\%29

Council of the European Union (2018a). Council recommendation of 15 March 2018 on a Europeanframeworkforqualityandeffectiveapprenticeships. OfficialJournalofthe European Union, C 153, 2.5.2018, pp. 1-6. Retrieved June 2, 2020 from: https://eurlex.europa.eu/legal-content/EN/TXT/?uri=CELEX\%3A32018Ho502\%2801\%29

Council of the European Union (2018b). Recommendation of 22 May 2018 on key competences for lifelong learning. Official Journal of the European Union

Council of the European Union; European Commission (2010). The Bruges Communiqué on enhanced European cooperation in vocational education and training for the period 2011-2O. Retrieved June 2, 2020 from: http://ec.europa.eu/dgs/education_ culture/repository/education/policy/vocational-policy/doc/brugescom_en.pdf

Council of the European Union; European Commission (2015a). Riga Conclusions 2015 on a new set of medium-term deliverables in the field of VET for the period 201520. Retrieved June 2, 2020 from: http://ec.europa.eu/dgs/education_culture/ repository/education/policy/vocational-policy/doc/2015-riga-conclusions_ en.pdf

Council of the European Union; European Commission (2015b). Jointreport of the Council and the Commissionon theimplementation of thestrategicframeworkfor European cooperation in education and training (ET 202O). New priorities for European cooperation in education and training. Official Journal of the European Union, C 417, 15.12.2015. pp. 25-35. Retrieved June 2, 2020 from: https://eur-lex.europa. eu/legal-content/EN/TXT/PDF/?uri=CELEX:52015XG1215(O2)\&from=EN

Council of the European Union; European Parliament; European Commission (2017). European pillar of social rights. Retrieved June 2, 2020 from: https://ec.europa. $\mathrm{eu} /$ commission/sites/beta-political/files/social-summit-european-pillar-socialrights-booklet_en.pdf

Council of the European Union (2018). Council Recommendation on automatic mutual recognition, adopted in November 2018.

Dede, C. (2009). Comparing frameworks for 21st century skills. Harvard Graduate School of Education, July 2009. Retrieved June 2, 2020 from: http://sttechnology. pbworks.com/f/Dede_(2010)_Comparing\%20Frameworks\%20for\%2021st\%20 Century\%20Skills.pdf

ETF (2018). Tracking vocational graduates in the EU candidate countries. Retrieved June 2, 2020 from: www.etf.europa.eu/web.nsf/pages/Tracking_graduates_ candidate_countries

European Commission (2011). Transferability of skills across economic sectors: role and importance for employment at European level. Luxembourg: Publications Office of the European Union. Retrieved June 2, 2020 from: http://ec.europa.eu/ social $/$ main.jsp?catId=738\&langId $=$ en\&pubId=6070\&furtherPubs=yes 
European Commission (2012). Rethinking education: investing in skills for better socioeconomic outcomes. COM (2012) 669 final. Retrieved June 2, 2020 from: https://eur-lex.europa.eu/legal-content/EN/TXT/ $\mathrm{PDF} /$ ?uri=CELEX:52012DCo669\&from $=\mathrm{EN}$

European Commission (2016a). High-performance apprenticeships \& work-based learning: 20 guiding principles. Luxembourg: Publications Office of the European Union, 2016.

European Commission (2016b). Staff working document: communication on a new skills agenda for Europe. Working together to strengthen human capital, employability and competitiveness. SWD (2016) 195 final. Retrieved June 2, 2020 from: http://ec.europa.eu/social/BlobServlet?docId=15621\&langId=en

European Commission (2017a). Communication to the European Parliament, the Council, the European Economic and Social Committee and the Committee of the Regions on establishing a European pillar of social rights. COM(2017) 250 final, Brussels, 26.4.2017. Retrieved June 2, 2020 from: https://eur-lex.europa. eu/legal-content/EN/TXT/PDF/?uri=CELEX:52017DCo250\&from=EN

European Commission (2017b). Recommendation of 26.4.2017 on the European pillar of social rights. C (2017) 2600 final, Brussels, 26.4.2017. Retrieved June 2, 2020 from: http://ec.europa.eu/social/BlobServlet?docId=17625\&langId=en

European Commission (2018a). Opinion of the Advisory Committee on Vocational Training on The future of vocational education and training post 202O. December 2018.

European Commission (2018b). Teachers and Trainers Matter. How to support them in high-performance apprenticeships and work-based learning. Retrieved June 2, 2020 from: http://www.bollettinoadapt.it/wp-content/uploads/2018/o9/KE02-18-612-EN-N.pdf

European Commission (2019). Education and training monitor, 2019. Retrieved June 2, 2020 from: https://ec.europa.eu/education/sites/education/files/documentlibrary-docs/volume-1-2019-education-and-training-monitor.pdf

European Commission et al. (2013). European alliance for apprenticeships: declaration of the European social partners, the European Commission and the Lithuanian Presidency of the Council of the European Union. Retrieved June 2, 2020 from: http://ec.europa.eu/social/BlobServlet?docId=14331\&langId=en

European Council (2013). Conclusions of the European Council of 7 and 8 February 2013 as regards the multiannual financial framework. EUCO 37/13, Brussels, 8 February 2013. Retrieved June 2, 2020 from: https://www.consilium.europa.eu/ uedocs/cms_data/docs/pressdata/en/ec/135344.pdf

European Parliament and Council of the EU (2006). Recommendation of the European Parliament and of the Council of 18 December 2006 on key competences for lifelong learning. Retrieved June 2, 2020 from: https://eur-lex.europa.eu/ LexUriServ/LexUriServ.do?uri=OJ:L:2006:394:0010:0018:en:PDF 
European Training Foundation (2018). Tracking vocational graduates in the EU candidate countries. Retrieved June 2, 2020 from: www.etf.europa.eu/web.nsf/ pages/Tracking_graduates_candidate_countries

ILO (2009). Core competency and values framework. Retrieved June 2, 2020 from: http://www.ilo.org/public/english/bureau/pers/download/list_of_ilo_ competencies.pdf

OECD (2005). The definition and selection of key competencies. Executive summary. https://www.oecd.org/pisa/35070367.pdf

Psifidou, I. (2019). Moving youth at risk from a trampoline to a safety net. In CedefopLifelong learning platform Policy Forum: What role for community lifelong learning centres? The potential of one-stop shops for preventing youth at risk from disconnecting. 29 May, Brussels.

Rustico L., David R. and Ranieri A. (2020). 'Apprenticeship' in the Italian approach to the dual system' In: European integration and the challenges of dual vocational training. Transfer $1 / 2020-$ special issue.

\section{Webliography}

Cedefop (2016). Cedefop's opinion survey on VET. Retrieved June 2, 2020 from: http:// www.cedefop.europa.eu/en/publications-and-resources/data-visualisations/ opinion-survey-on-vet

Cedefop (2019). Cedefop's VET toolkit for tackling early leaving. Retrieved June 2, 2020 from: https://www.cedefop.europa.eu/en/toolkits/vet-toolkit-tackling-early-leaving

European Commission (2017). European Commission's web page on education initiatives: recommendations on key competences for lifelong learning. Retrieved June 2, 2020 from: https://ec.europa.eu/education/initiatives/key-competencesframework-review-2017_en 